\title{
日本・韓国・台湾伝統建築外観のイメージ特性 \\ A STUDY ON THE IMAGE OF THE APPEARANCE FOR JAPANESE, KOREAN AND TAIWANESE TRADITIONAL ARCHITECTURES
}

\author{
金 東 永*1, 岡 島 達雄*2, 麓 和善*3, 内藤 昌*4 \\ Dongyoung KIM, Tatsuo OKAJIMA, Kazuyoshi FUMOTO \\ and Akira NAITO
}

\begin{abstract}
The comparison of traditional architectures between countries makes the characteristics be more objectively. This paper is a synthesis of the image of the appearances for Japanese/Korean and Japanese/Taiwanese traditional architectures through the their subjects' cognitive structure. The images for all architectures in this research were mainly in modestyorder, strictness-hardness, and looseness-softness. The members which strongly influenced on the image are roof and column/wall with various layouts, shapes and colors. The common image in those architectures is modesty and order, representing harmony of nature. Japanese subjectives are represented as to be stricter and harder than Korean or Taiwanese. On the other hand, Korean or Taiwanese as to be looser and softer than Japanese, which was considered as related with the idea of their high level at that period.
\end{abstract}

\section{Keywords: Japanese traditional architecture, Korean traditional architecture, Taiwanese traditional architecture, appearance, image \\ 日本伝統建築, 韓国伝統建築, 台湾伝統建築, 外観, イメージ}

\section{1 序}

建築空間は、文化・風土などによってその構成と表現およびイ メージが違っていて、そのような特徵は特に、地域土着性の強い伝 統建築によく表れていると考えられる。古来から中国文化すなわち 漢字文化圈の諸国は、中国を原点とする幅広い分野における密接な 交流を通して、漢字文化圏という大きな文化の下で国々独特の文化 を作り上げてきた。同じく各国の伝統建築空間においても、漢字文 化圈の共通の空間的な特性と各国独特の空間的な特性が、ともに共 存しているのであろう。さらに、異国の伝統建築との比較を行うこ とは、各国の伝統建築空間の特徵が一層客観的に捉えられると考え られる。このような背景から本研究は、漢字文化圏の諸国の中でも、 昔から密接な関係をもって成長し、現在は各々の独自の文化を創出 している日本と台湾そして韓国、この三力国の伝統建築外観を対象 としてそのイメージを、三カ国の被験者による心理実験を行い、4 漢字対（華一寂、剛一柔、厳一笑、整一雑）を用いて表し、そのイ メージ想起に影響が強い部位（屋根、組物、柱・壁、縁・階）・要素 (配置、形状、凹凸、図柄、色彩、光沢、材質感)の関係から探って みた注1.2、3)。本稿ではいままでの結果を用いて三力国外観のイメー ジの共通点・相違点を明らかにし、その意匠特性を総合し、比較考 察する。

\section{3 力国伝統建築外観の共通的イメージ：「寂」「整」} 3 力国対象物は、おもに「寂」「整」「厳」「剛」「笑」「柔」のイ メージ特性を示し（図 1、2)、構成部位では「屋根、柱・壁小、要 素としては「配置、形状、色彩」の指摘頻度が高い（図 3 )。しかし、 被験者の対象物に対するイメージの違いは、着目部位の違い（相手 国の対象物に対して、自国の対象物にはあまりみられない部位を指 摘する傾向) - 相対的着目要素の違い (日本被験者一色彩、韓国被験 者一形状、台湾被験者一図柄）によって発生すると考えられる。一 方、「寂」「整」のイメージは屋根及び柱・壁の単調な形状と色彩か らの影響が大きく、「厳」「剛」は大きい屋根、跳ね上がった鋭い軒 先、柱・壁の垂直・水平の形状と無彩色系統の色彩、また石の材質 感からの影響が大きく、「笑」「柔」は屋根の曲線的な反り、柱・壁 の曲線的な形状および有彩色の系統の色彩、木の材質感、さらに開

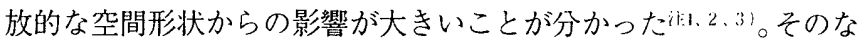
かで、相対的に日本の対象物は「寂」「整」「峳」「唰」の特性を、韓 国そして台湾の対象物は「寂」「整」「笑」「柔」の特性を表すもの が多かった。これを用いて判断すると、3 力国対象物からは「寂」 「整」のイメージが共通的特性であり、「厳」「剛」「笑」「柔」のイ メージは個別的特性といえる。この「寂」「整」のイメージは、住宅 建築を中心として寺院・神社・城郭建築の一部を除いたほとんどの

本稿は，日本建築学会大会畍において発表した内容を修正および加筆したものである。

*1 世明大学産業建設環境工学部建築工学科 専任講師.工博

*2 名古屋工業大学 学長. 工博

*3 名古屋工業大学工学部社会開発工学科 助教授・工博

*4 愛知産業大学建築学科 教授. 工博 


$\begin{array}{ll}1 & \text { 金地院 方丈 (住宅) } \\ 2 & \text { 平等院鳳凰堂 (寺院) } \\ 3 & \text { 金地院八空席 (茶室) } \\ 4 & \text { 相国寺法堂 (寺院) } \\ 5 & \text { 角屋 (住宅) } \\ 6 & \text { 日吉大杜東照宮 (神社) } \\ 7 & \text { 園城寺 金堂 (寺院) } \\ 8 & \text { 光浄院 客殿 (住宅) } \\ 9 & \text { 浄土寺浄土堂 (寺院) } \\ 0 & \text { 姬路城天守 (城郭) }\end{array}$
11 鳳停寺極楽殿（寺院）
2 三可轏荷葉亭 (別堂/茶室)
3 華簃寺覚皇殿 (寺院)
14 棌束满家屋 (住宅)
15 道東著院柌堂 (祠堂/神社)
16 修德寺大崔明 (寺院)
17 養真堂 (住宅)
18 通度寺大雄殿 (寺院)
19 三可軒舎廊棟（住宅）
20 南韓山城守罆将台 (城郭)

21 摘星山荘 (住宅)

22 台南孔子廟大成殿（文教/神社）

23 台北龍山寺正殿 (寺院)

24 林安泰宅 (住宅)

25 鄭山寺正殿 (寺院)

26 底港龍山寺 (寺院)

27 馬興陣宅 (住宅)

28 開元寺正殿 (寺院)

29 林本源庭園方籃成（庭園/茶室）

30 承恩門 (城郭)
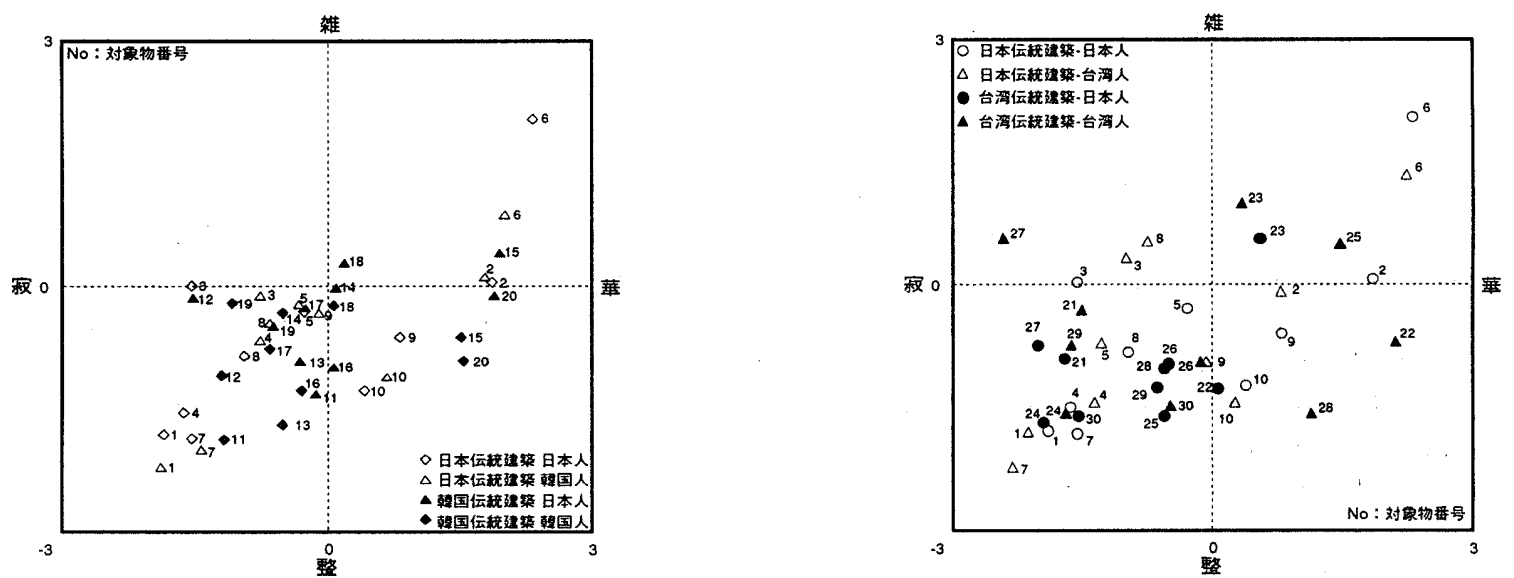

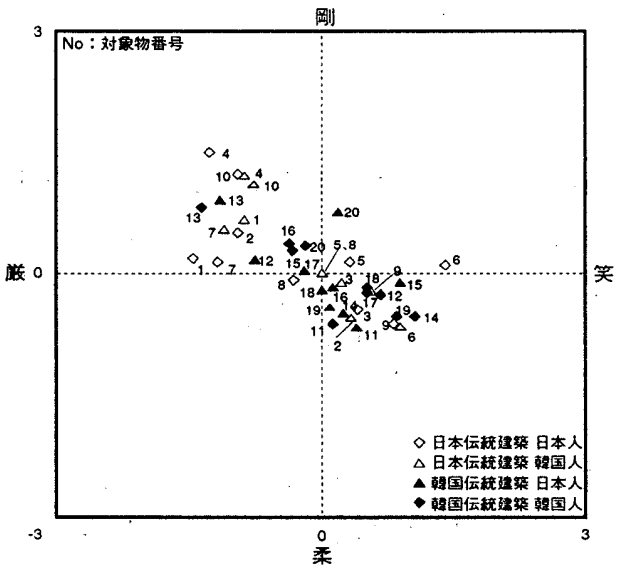

図1対象物のイメージ（日本・韓国）

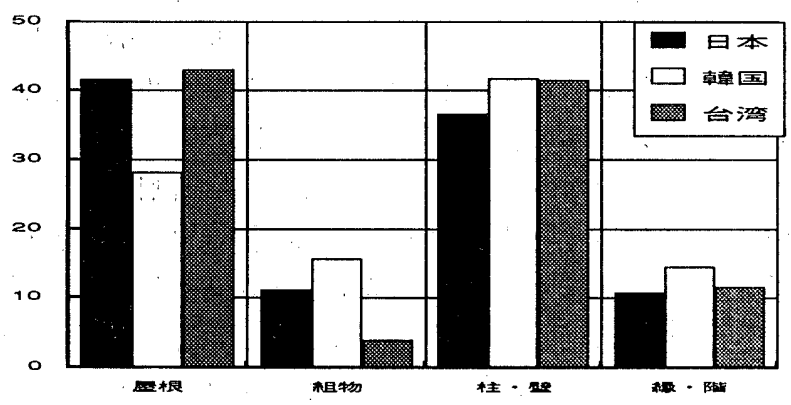

部位

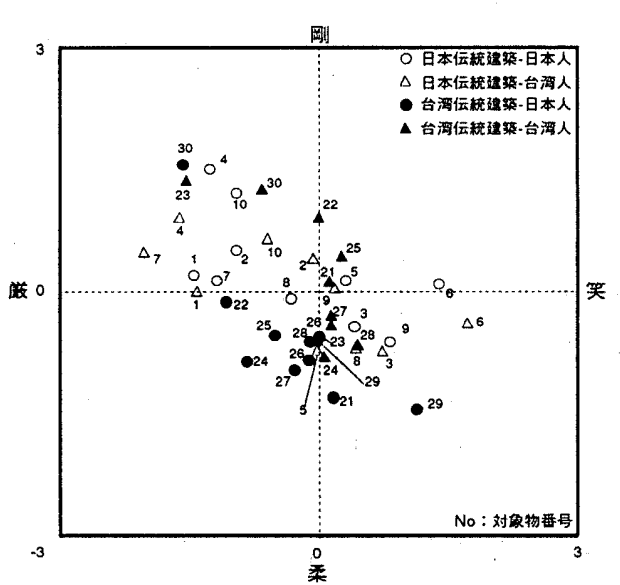

図2、対象物のイメージ（日本・台湾）

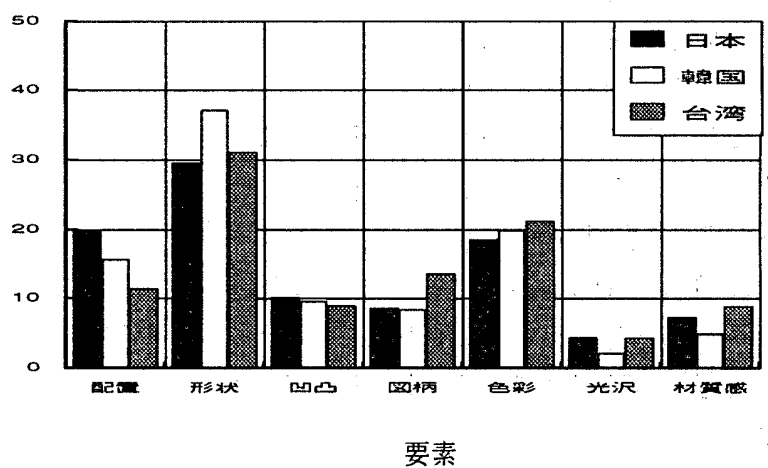

要素

図 3 各国対象物の指摘頻度\% 
対象物から表れているが、それは対象物の全体的なイメージで屋根 の単調なシルエット、柱・壁の白・茶色と赤色系、黄色系など単色 の淡い彩色による影響が大きいことが分かる。

古来から 3 力国の伝統意識の基本の中では、「自然と共に生きてい 〈」という思想注5)すなわち自然との調和、自然との融合の精神が 根強く存在している。建物を建てることにしても、周りの環境と調 和がとれるように工夫した。従って、建物の色々な部分でそのよう な特性が表れることは自然的結果ともいえるが、本研究の三力国の 対象物からは素朴で落ち着きのある「寂」整」のイメージで表現さ れていると考えられる。

\section{3 力国伝統建築外観の個別的イメージ}

\section{3-1 日本一「厳」「剛」}

日本伝統建築の屋根は、韓国、台湾伝統建築とのイメージの違い を形成する主な要因として表れた。漢字文化圏の諎国では建物を高 く大きく見せたいという願望が動いていただろう注ら〉が、外観にお いて日本伝統建築の屋根は、韓国と台湾建築の屋根より相対的に大 きい。日本には、飛鳥時代に六朝・隋の建築様式が韓国を経由して 伝来し、奈良時代に唐の様式が伝来してきた注7)。これらの初期の建 築様式は大陸様式と変わりがなかった。屋根構造も、軒先に見える 化粧垂木が母屋上で折り曲げられながら棟まで達し、その上に茸き 土をのせて瓦を葺く大陸の技法そのままであった。したがって屋根 勾配も緩かった。しかし、降雨量が多い日本では雨もりがしやすく、 その修理も化粧材にまでおよび、大規模となる。そこで、平安時代 になると、軒裹（化粧垂木）は勾配を可能な限り緩くして軒先の垂 下を防ぎ、屋根（野垂木）は勾配を強くして雨仕舞をよくすること を目的として、「野屋根」が考案された注8)。法隆寺大講堂 (990年) が、その現存の最古の例として知られている。この野屋根の発生に より、下部構造と屋根構造は、必ずしも一致しなくてもよくなり、 従来梁間の大きい建物は、母屋・庇の全面にさらに孫庇を付加する か、あるいは二棟を並列する双堂形式でしか成立しなかったのを、 この双堂形式の屋根の上にさらに大屋根を造ってひとつの建物とす る架構法へと発展した。当麻寺本堂 (曼茶羅堂 1161 年) がこの好例 である。また、軒の化粧垂木との屋根の間に買ができたのにともな い、桔木によって軒を支えることを考案し、さらに軒を深くする一 方、化粧垂木の断面は小さく繊細にすることが可能になった。そし て、一旦野屋根を発明すると奈良時代以前の建築も鎌倉時代の改造 で野屋根形式に改造された。この日本独特の「野屋根」の登場によ り、以後日本伝統建築の外観において屋根は、勾配が強く屋根全体 のヴォリュムも大きくなって、立面上屋根の占める比率が著しく大 きくなった。さらに、近世になると、屋根を大きくするために破風 の立ちどころを前方へ出したり、千鳥破風、唐破風を付けて装飾す ることが流行するが、その極限が権現造で、霊廟などに時の権力者 が自己の権力誇示として好んで用いた（図 4)。そして、伊藤は「弥 生時代に階級社会が成立して以来、屋根なるものは単に風土に適応 せざる得ない形式をとっていたばかりでなく、同時に身分すなわち 社会的地位の象徴でもあって、屋根の高さは同時に建物の高さであ り、それは社会的地位の象徴だったのである」注9）と述べている。ま た、日本伝統建築では、瓦葺・桧皮葺・柿葺・茅莫など屋根苟材に よって建物の格を表しており、これも意匠上重要な要素となってい

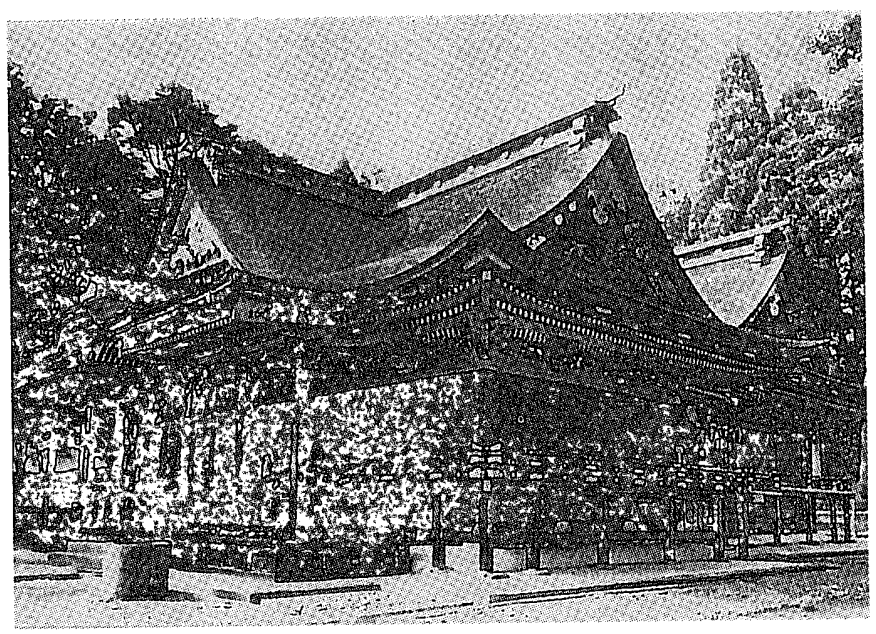

図 4 大崎八番神社 社殿

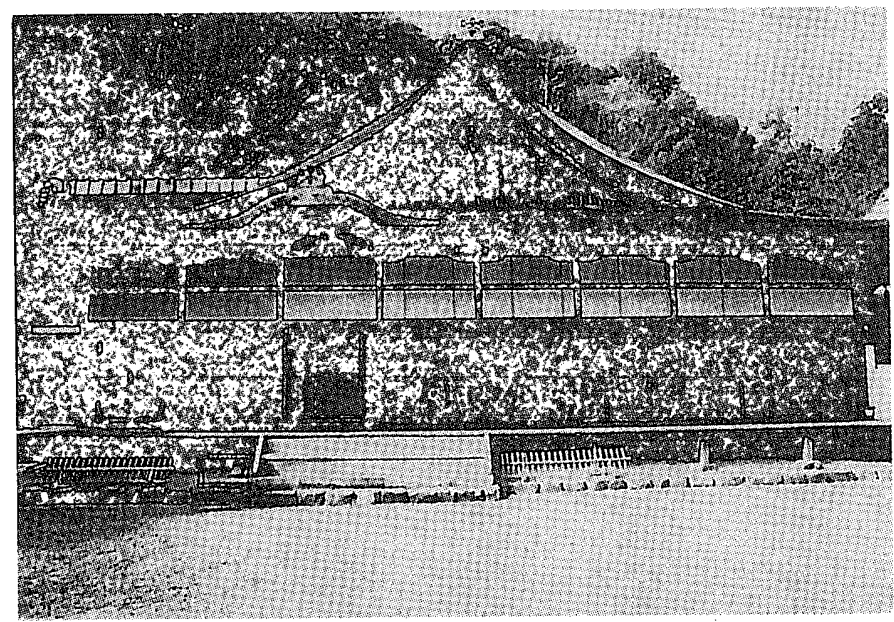

図 5 光浄院 客殿

る。そして、屋根の反りにおいては、大棟の反りは比較的少ないの に対して、軒先端には跳ね上がるような反りが見られ、それが鋭い 感じを与えている。以上のような日本伝統建築の屋根の特性が、韓 国・台湾の対象物より相対的に「厳」「剛」のイメージを与えている と考えられる。

次に、日本伝統建築の外観の柱・壁においては、韓国・台湾建築 より直線的な形状と白と茶色の色彩が日本的な特性として表れてい る。格子・障子・連子悹・裳階の柱および真壁造の軸部などの直線 的な形状と、漆喰壁と障子の白色と軸部の茶色がそれである（図 5 )。色彩において、日本伝䋨建築は台湾および韓国伝統建築に対し て、白と茶色の色彩が目立つが、その茶色は屋根と軸部の木材が時 間の経過に従って変色したものである。日本対象物は 3 力国の対象 物の中、外観に彩色がもっとも少ない。大陸から建築様式が伝来さ れた当時には大陸並の彩色が施されたが、時代の降るとともに、彩 色が少なくなる。神社建築、特に神明造や大社造においては、素木 のままであり、色彩は素材そのままの色であって、装飾的な気分を もたない。寺院のうちにも素木造りのものが多くなり、中国・宋時 代の様式を受けついだ禪宗建築においてさえ、一・二の特例のほか は、全く彩色を施さない注10)。全般的に日本伝統建築外観において、 柱・壁部分での彩色および彫刻などの装飾は、韓国、台湾伝統建築 
に比べると相対的に少ない。また、3カ国の伝統建築の色彩におい て、基本色 - 赤 · 青 : 黄 - 白 ·黒 - は同じであるが、同じ系列の色 でも施されている色は多少違いをみせている。

上記のように日本伝統建築外観において、日光東照宮、日吉大社 東照宮などの一部の例外を除いて全般的に柱·壁には装飾性が少な く、障子・連子空・縦格子および真壁造の軸部などの直線的形状と 白と茶の色彩が目立つ。このような特性が、韓国・台湾の対象物よ り相対的に「厳」「剛」のイメージを表すもうひとつの重要な要因 であると考えられる。

以上の特性によるイメージの違いは、台湾対象物との比較では寺 院建築、韓国とは住宅建築でよく表れる。

\section{3-2 韓国一「笑」「柔」}

韓国伝統建築には、中国の影響が強い。屋根構造は、現在に至る まで軒先に見える化粧垂木が母屋上で折り曲げられながら棟まで達 し、その上に茸き土をのせて瓦を茸く大陸の技法そのままである。 屋根勾配も緩い。従って、立面上の屋根面積は日本伝統建築に比べ ると相対的に少ない。屋根曲線においても高麗時代はもちろん朝鮮 時代末期まで、緩やかな曲線すなわち古代手法で一貫してきた注川 (図 6 )。そのような緩慢な屋根の曲線的な特性は、韓国伝統建築の 全種類においてよく見られる。韓国は地質学的に老年期の地貌に なっているため、緩やかな曲線の山頂峯が多く小さい丘陵の隼平原 になっていて、ここで建てる建物が高くなったり、ヴォリュムが大 きくなると周りの環境と調和できなくなる。すなわち、背景として の山と小さい丘陵に建てる建物の関係は、中庸的な立場をとらざる を得なくなる注12)。このような環境は韓国伝統建築の独特な形態構 成に大きな影響を与えた。すなわち、屋根の大棟の線は、大棟の両 端が上げられ中央が下がり柔軟な曲線をなし、軒の曲線も大棟の曲 線と調和をなして重く見えがちの屋根面を軽快に見せてくれる。そ の大棟の強さにおいては、台湾と日本の中間的な形状を示してい る。

屋根茸材は、茅や板を使った民家以外のほとんどの建築に瓦が用い られている。一方、韓国伝統建築の屋根には、台湾伝統建築の大棟 の上に見えるような装飾は見られないが、同様な性格の奇異なる人 物の像や鬼龍子形状の装飾が宮殿建築の隅棟によく見える。このよ うな特徴をもつ韓国伝統建築の屋根には、中国の陰陽五行説などを もとに韓国の時代的思想が反映され、韓国的特性を表現していると 考えられる。柱・壁においては、台湾ほどではないが、彩色と空お よび戸の栈の模様が特徴的である。ほとんどの建築の柱・壁には彩 色されているが、その中でも祠堂建築と宮殿建築はもっとも彩色量 が多い。しかし住宅建築には漆喰壁の白色と軸部・空·戸の木材の 茶色だけが見える。日本伝統建築の茶色と比べると同じ木材の経年 変化による茶色でありながらその濃淡において、韓国は淡く日本は 濃い。育および戸の栈には、漢字文字形、方形、ひし形、花柄など の色々な模様の繊細な装飾で飾られているが、建築の種類によって 使われている模様が異なる。柱・壁の彩色および彫刻などの装飾的 な面の雨面において、韓国伝統建築は台湾伝統建築と日本伝統建築 の中間に位置する。

一方、韓屋と呼ばれる韓国の住宅の主な特性の中では、意匠的空 間的なものとしてのマル注13) (板の間) と設備的ものとしてのオン

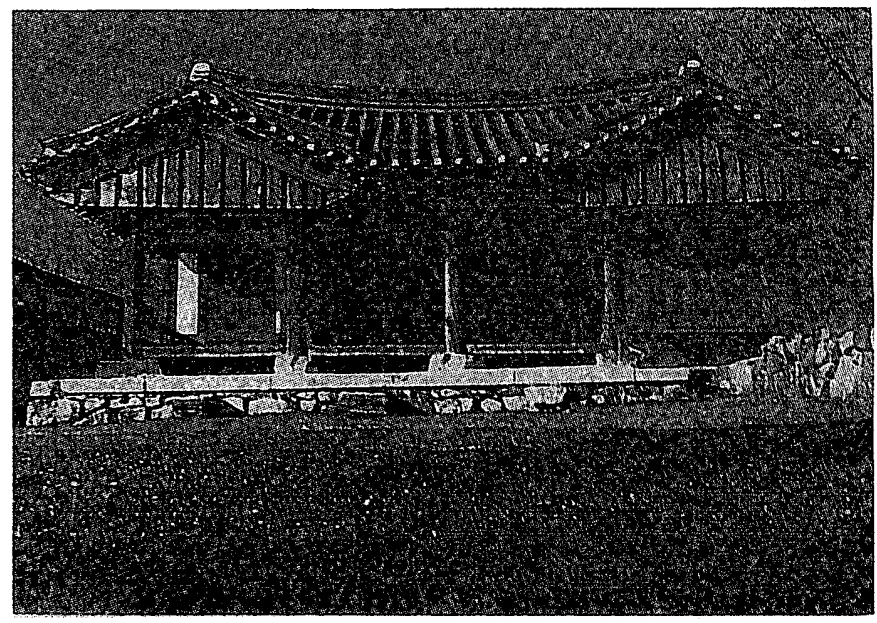

図 6 香檩 舎廊棟

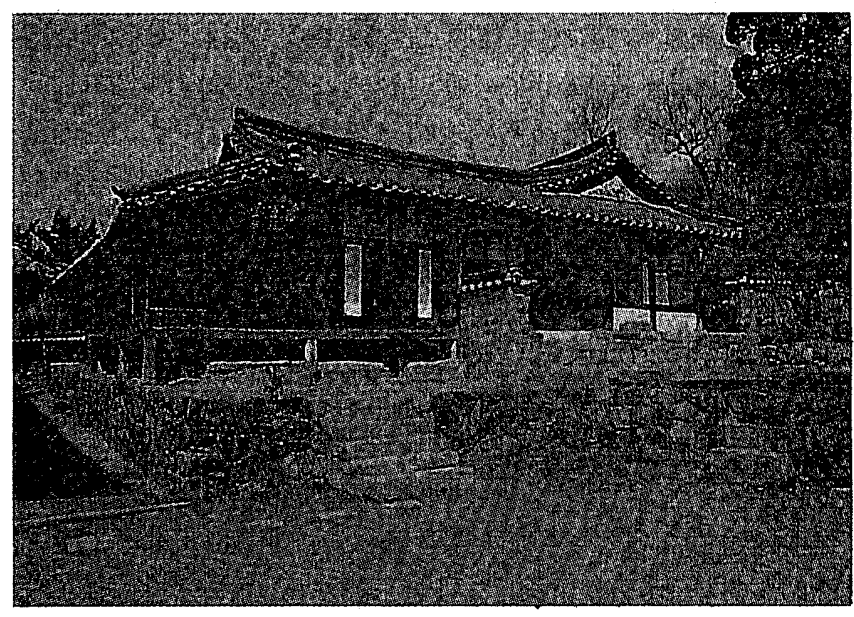

図 7 孫東萬 家屋

ドル (温突) がある。本研究では縁に分類されているマルはもともと 地温・地湿を防ぐための構造であったが、その機能は倉庫、蔵書、民 家での祭祀、夏の生活の場、部屋と部屋との連結通路、部屋とマダン 注14) との間の中間領域などに多様に使われた。また、マルはマダンに 開放されそれを支配するという意味で、住宅の開放的な中心空間であ る。しかも、その天井の木造構造がそのまま露出されて、空間が断面 的にも拡張されるし、外の部分より高い位置を占めて、その開放性と 中心性が一層強調される (図 7 )。韓国伝統建築の韓国人の生活習慣 と意識構造に深く影響を与えたマルは、三国時代以前から発生し、三 国時代になって一層発達して主に上流住宅に取り入れられた。高麗時 代になってからその使用がより一般化され、特に高麗末には寺院にも マルを設ける傾向が現れる。朝鮮時代には家舎規制の身分の高下に よって楼の間数を制限したが、これはマルが身分の高貴性と権威性及 び象徵性を表しているためである注15)。このように、韓国上流住宅の 構成の基本には自然と儒教の倫理が根強く存在している。

韓国伝統建築外観の特性においては、緩やかな大棟の反りと.住宅建 築の開放的な形状のマルなどが韓国的特性として指摘され、それらは 「笑」「柔」のイメージを表している。その中でも、衣食住に制限が あった昔、韓国上流階層の思想的・身分的象徴の所産物であった住宅 
建筑のマルは韓国的イメージの代表的な部位である。

\section{3-3 台湾一「笑」「柔」}

台湾伝統建築は、もとと中国南部の福建南部と広東東部の様式 からの影響が大きい。中国伝統建築において、北部は直線、奔放、素 朴、南部では曲線、耽美、明澄な風格によって南北の人々の性格を 表現している(注16)。屋根様式も、軒先に見える化粧垂木が母屋上で折 り曲げられながら棟まで達し、その上に茸き土をのせて瓦を茸く大 陸の技法そのままである。屋根勾配も緩い。このような特性をもっ ている台湾伝統建筑の屋根の立面上の面積は日本伝統建築に比べる と相対的に少ない。また、非常に曲線感溢れる大棟の反りとその上 に設けられている多彩な装飾などが台湾的特性として表れて、それ らは「笑」「柔」のイメージを与えている。3 カ国対象物の大棟の反 りに执いては、台湾が一䧽く、韓国そして日本の順である。大棟 の装飾は、日本・韓国伝統建築にもあるが、台湾伝統建筑ほどでは ない。台湾伝統建築の軒反りは、比較的少ないのに比し、棟の反り が著しく強い。また、その両端には燕子尾という反りがあるが、そ の鋭い形状は曲線感溢れる大棟の反りのイメージを抑えるほどでは ない。一方、簡単な家では両端に反りがなく、馬背式という。大棟、 下り棟などには漆喰の表面に陶磁器の破片を巧みに並べて、楼閣・ 神仙・需獣または花弁などを作り上げ、ぎっしりと詰め込む注17)。大 棟両端と同じく、下り棟下端には青龍または黄龍が用いられている。 また、大棟の中央には神仙三体の群像、または宝珠などが飾り上げ られている。屋根葺材としては、民家以外のほとんどの建築に瓦と 磚を使っているが、建物によっては赤色のものを使う場合もある。 また、瓦の形状と咠かれた形状は日本と韓国より多様な変化を見せ ている。(図 8)

以上、曲線感溢れる大棟の反りと、非常ににぎやかな装飾から、 「笑」「柔」のイメージが生じていると考えられる。

一方、外観の柱・壁においては、3 カ国の中でもっとも彩色が目 立つ。日本と韓国とは異なって、台湾伝統建築においては種類に関 わらずほとんどの建物に有彩色の色彩が用いられている。こ机には 建築部材に着色ある外に、赤煉瓦など最初から色のついた材料を用 いた建物もある。空戸には、中国伝統思想の内容が様々な形状で表 れている。さらに空戸の枠、栈などには繊細な装飾が飾られている。 また、寺院建築の龍柱は台湾伝統建築のもうひとつの特徵である。 円形の石柱の上に生きている感じのような龍が飾られているが、石 の材質感および龍の形状は主に「厳」剛」のイメージを与えている。 とりわけ、台湾伝統建築の柱・壁には中国伝統思想の内容が様々な 装飾で飾られていることが特徴である。(図 9)

このように、神仙思想と陰陽五行説などに基づいている大棟の曲 線的な形状と、その上に飾られている多彩な形状や色彩に富んた装 飾は、台湾伝統建築外観のイメージをより「笑」「柔」の側に向かわ せている。寺院建築でその現象が著しいといえる。一方、韓国伝統 建築外観の特性も「笑」「柔」のイメージで現れたが、緩やかな大棟 の反りとマルの開放的な形状などが主な原因として指摘された。し たがって、共に「笑」「柔」のイメージで示されてもその原因は異 なっており、大棟の反りは台湾对象物がより強く、韓国対象物では 開放的な空間が、台湾対象物では多彩な形状や色彩に富んた装飾が そのイメージに影響しているということが特徴的である。

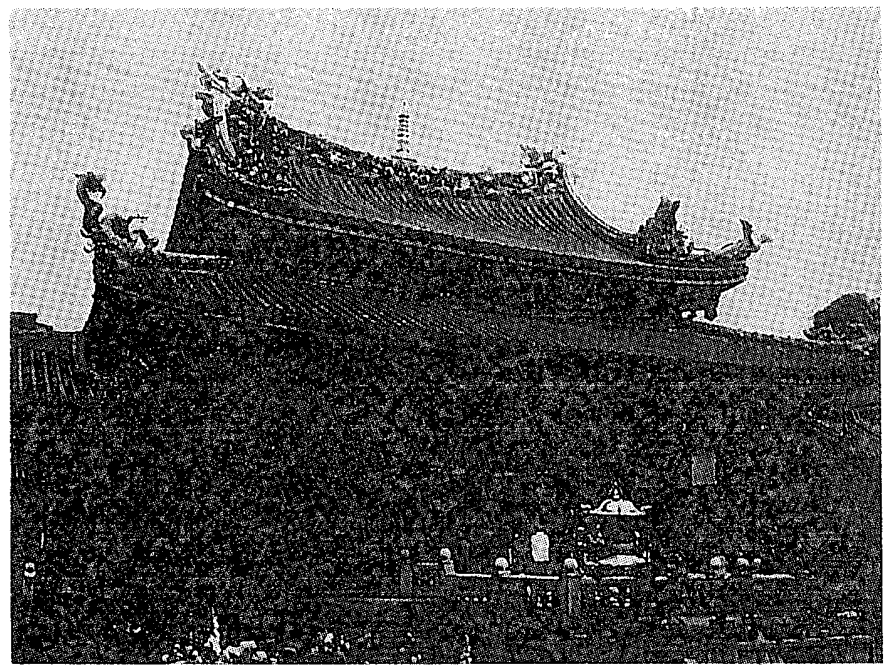

図 8 台北 龍山寺

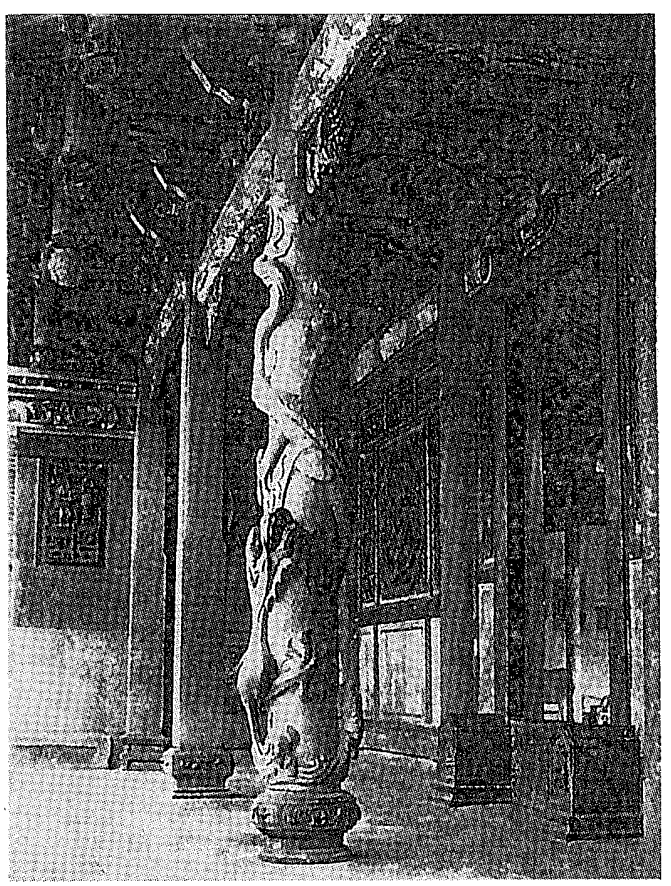

図 9 鹿港 龍山寺

\section{4 結論}

1）日本、韓国、台湾対象物の外観の共通的なイメージ特性とし ては、「寂一整」のイメージが表れ、各国の個別的なイメージ特性は 「厳一剖」、笑一柔」のイメージで把握できる。「寂一整」のイメー ジは対象物外観の全体的な面の素朴で質素な感じの単調な意匠から とられているが、3 力国共通の自然調和思想の表現と考える。個別 的特性は、日本の対象物は主に大きい屋根と軒先端の跳ね上がる形 状、真壁造の軸部と障子・縦格子などの水平・垂直的な直線と白と 茶の色彩影響による「厳」「剛」のイメージ特性が、韓国対象物は、 緩慢な屋根曲線、マルの開放的な空間と柱・壁の淡い有彩色の 影響による「笑」「柔」のイメージ特性が、そして台湾对象物は、屋 根の強い曲線、多彩な装飾と柱·壁の有彩色の影響による「笑」「柔」 のイメージ特性があげられる。 
2 ）建築空間は、時代の流れと技術の進歩にともない、拡充、分 化され、その上意匠化される。それらはその地域の風土、宗教、思 想などの様々な文化の影響を受けている。しかし、政治と宗教が緊 密に関係し、その上支配階層の影響が社会全般において絶対であっ た封建時代には、自然環境すなわち風土の影響より、主たる宗教に 基づいた支配階層の思想が建築空間の形態に大きく影響を及ばした と考えられる。また、一般的に生活様式は、支配層から下部階層に 普及する傾向があるが、国際間の文化は支配層から支配層に伝播す ることが多い。本研究の日本、韓国、台湾対象物の発生背景にも同 じ状況があった。その当時日本は公家層、あるいは武士層が、韓国、 台湾は文人層が支配階層を形成していたが、このような権力の流れ および彼らの主な思想は、建築空間の構成と深い関係があったと考 えられる。従って、対象建築物外観のイメージ特性は、建設当時の 各国支配階層の主な思想の象徴的表出であると考えられる。さらに、 そのイメージ特性は、当時 3 力国支配階層の共通の自然調和の東洋 思想と各国独自の時代思想が深く関係していたと考えられる。

注

1）岡島達雄、金 東永、簏 和善、内藤 昌: 日本 - 韓国伝統建筑空問の イメージ評定尺度抽出一日本·韓国伝統建築空間のイメージ特性（その1)、 日本建築学会計画系論文報告集、第 458 号、pp.171- 177、1994 年 4 月

2）岡島達雄、金 東永、簏 和善、内藤 昌: 構成部材·要素加々た日本· 韓国伝統建築空間のイメージ特性一日本・韓国伝統建築空間のイメージ特 性（その 2)、日本建築学会計画系論文報告集、第464号、pp. 209-214、1994 年 10 月

3）金 東永、岡島達雄、麓 和善、黄 武達、内藤 昌: 日本·台湾伝続建 築空間のイメージ特性、日本建築学会計画系論文報告集、第 475 号、pp. 203208、1995.年9月 1)
4）金 東永、岡島達雄: 日本・韓国 ·台湾伝統建築空間のイメージ特性、日 本建筑学会学術講演梗概集 (北海道)、F券、pp.351-352、1995 年 8 月

5）たとえば、太田は日本人の建築覾に対して「建筑家の目標としたのは、大 地を踏まえて立つ堂々たる建築ではなくて、いかに自然と調和する建筑を 作るかにあった」と述べている。（太田博太郎：日本建築史序説、榇国社、 1990 年、p.13)

6）たとえば、細見啓二、「中国宮殿にみる二、三の問題」(岸俊男糄、「中国の 都城遺跡」同朋社、1972 年、所収）では紫禁城太和殿を例に、高い基台を 用いた高さへの志向、整然と組まれた斗栱の豪華さ、勾配を高屋根の量 塊性の三つを中国宮殿の建築的特性としている。

7) 太田博太郎：日本建筑史序説、彰国社、1990年、pp.7.8

8）浅野 清: 奈良時代建䇣の研究、中央公論美術出版、1969 年、pp.58-62

9）伊藤ていじ：日本の屋根、丵文社、1982 年

10 ）太田博太郎：日本建筑史序説、彰国社、1990年、p.37

11 ）朴 彦坤：韓国建築史請論、文運堂、1993、p.184（韓国）

12 ）朱 南哲：韸国建築意匠、一志社、1979、pp.198～199 (韓国)

13 ) 板敷きの間、あるいは板間のことである。オンドル房は閆鎖的で天井·壁· 床のすべてに紙を貼りめぐらせているのに対して、マルは開放的で小屋組 が見える。(金 奉熱 著、西垣安比古 訳: 韓国の建築一伝統建築編、学 芸出版社、p.287、1991 年)もともと地温・地湿を防ぐための構造であった が、その機能は倉庫、蔵書、民家での祭祀、夏の生活の場、部屋と部屋と の連結通路などに多㥞に使われた。(金，光鉝：建筑の巡礼20-韓国の住宅 ，丸善、1991 年、 $\mathrm{p} .80)$

14 ）マダンは、物理的な庭のみならず、場所とか中間領域の意味をも表す。マ ダンはわれわれの民族の固有な生活空間である。家の前後に固く平らに均 した土地、すなわち、マダンは常に寛大で事欠かなく受け入れる安らぎの 場所であった。マダンは、われわれ家族を着うための衔がねばならない「仕 事場」であり、苦しい一日が終わり重なった疲れを忘机てくつろぐ「休み 場」であり、村が一体になって興を湧かすお祭りの「遊び場」でもあった。 つまり、マダンはわれわれにとって、最も大切な生活の拠り所だったので ある。(金 光鉉：建築の巡礼 20-韓国の住宅，丸善1991 年、p.71)

15）李 鎬洌：マルの構造と類型、建筑文化、1979、p.26(韓国)

16）李 乾朗：台湾建筮史、雄榔美術、1979 年、pp.15－16 (台湾)

17 ）藤島茋治郎：台湾の建筑、彰国社、1948年、pp.93 96

18 ）大岡 実: 日本建築の意匠と技法、中央公論美術出版、1971 年 